\title{
Winds of Change in Saudi English Textbooks: A Cultural Perspective
}

\author{
Syed Md Golam Faruk \\ King Khalid University, Abha, Saudi Arabia
}

\begin{abstract}
The paper investigates Saudi English textbooks in order to trace the ways in which culture was dealt with in the English curriculum in the last 33 years. To this end, the three textbooks which were published one after another for the third-grade secondary school students in the last three decades were analyzed. The paper finds that in the first book published in 1982, the writer introduced only those cultural elements from outside Saudi Arabia, which could be subordinated to the self-enclosed cohesive Saudi national culture that rested and was shaped on and around the faith of Islam. The same cultural pattern is maintained in the second book published in 1998, but in the third book published in 2013, a huge number of western and multicultural elements were accommodated without any attempt to assimilate them to Saudi national culture. The paper concludes that in these textbooks, culture was taken either as Parsons's "system" - pattern-maintaining national culture — or as Rothkopf's and Friedman's "pattern-breaking" western culture, but it was seldom treated as Bauman's "matrix".
\end{abstract}

Keywords: Saudi Arabia, English textbooks, culture, system, matrix

\section{Introduction}

In Saudi Arabia, the style and content of the English textbooks changed as the state gathered pace in its journey towards the center of Wallerstein's modern "world system" (2006). The English textbooks that were used in 1924, when the country had to introduce ELT (English Language Teaching) in its formal education system to enter into the "periphery" zone of the capitalist world economy, are different from the books published in the 1980s and in the 1990s when it already established itself as a middle-income state. In the same vein, the books published in 2013 are completely different from the books published so far as the polity is determined to move with an unprecedented speed to the "core" zone of the modern "world system". In this context, the paper examines the reading texts of Saudi school-level English textbooks in order to trace the ways in which the textbooks have dealt with cultural elements for the last 33 years by analyzing three third-grade secondary school textbooks published consecutively over three decades. The three books-Saudi Arabian Schools' English published in 1982, English for Saudi Arabia published in 1998, and Traveller 3 (pilot edition), KSA (Kingdom of Saudi Arabia) edition of a global course book published in 2013-have been chosen as they represent the style, language, illustration, methods, and content of all the textbooks used during the same time at elementary, intermediate, and secondary levels in all the public schools of Saudi Arabia. The reading texts of all these three books are categorized as "Islamic", "Saudi", "Western", "multicultural", and "culturally non-specific" on the basis of Cortazzi and Jin (1999) in order to get a clear idea about the particular cultural 
elements in which the books contextualize English. Only the reading texts are explored here because they characterize the books in terms of culture and they get more attention in the classrooms than the texts given to develop the other skills. The paper finds that the first two books were produced almost on the same line focusing only on Islamic and Saudi cultural elements, but the third book took a new stance to accommodate a substantial number of Western, as well as some multicultural elements marginalizing but not contradicting the religious and local ones.

\section{Conceptualizations of Culture as "System", "Matrix", "Hegemon", and as a Means of Teaching English as a Second Language}

In this section, I shall review the conceptualizations of culture as "system", "matrix", "hegemon", and the ways in which it is used in English language textbooks as well as their impact on English language learning.

\section{Culture as "System"}

Talcott Parsons $(1937,1966)$, who labels himself a cultural determinist, conceived of culture, along with society and personality, as a "system". In such a "system" all the items are interconnected with and dependent on each other as the state of an item depends on the states assumed by other items. Hence, the play of an individual item is always constrained by the network of other items. If the network is strong and can keep the items under control, it means it is in equilibrium.

In order to be in equilibrium, the "system" needs strongly guarded borders to limit the movements across the boundaries as uncontrolled border passages might pose a threat to the established network. Sometimes, in order to cope with external situational exigencies, it may allow something from outside but that must be modified to fit it, which means the foreign elements must go through a process of adaptation and accommodation so as to be transformed and assimilated by the "system". In this way, a "system" furnishes, maintains, and renews the certain patterns in order to achieve its clearly defined primary goals.

In short, a "system", as discussed above, has four functional imperatives (Ritzer, 1996, p. 237) - (1) adaptation (adapting the environment to its needs), (2) goal attainment (defining and achieving the primary goals), (3) integration (regulating the interrelationship of its component parts), and (4) latency (maintaining the pattern). Parsons (1937) believes that these functional imperatives are necessary for all systems including “cultural system". Parsons's "cultural system" resonates in Fang's (2011) static paradigm of culture which assumes that it is possible to simplify the complex concept of culture in order to understand it and that a culture can remain unchanged over a long period of time.

\section{Culture as "Matrix"}

Although Parsons (1977) makes a major shift in his work to the study of social change later on, in view of most observers, he still tends to be highly static and structured. This is the reason why Zygmunt Bauman (1999) heavily criticizes the Parsonian version of the orthodox view of culture. For example, when Parsons says that there is no scope for change unless a culture malfunctions; Bauman asserts that a culture breaks down if it resists change. To Parsons, change is a puzzle whereas to Bauman it is a necessity. According to Bauman (1999):

Culture is as much about inventing as it is about preserving; about discontinuity as much as about continuation; about novelty as much as about tradition; about routine as much as about pattern-breaking; about norm-following as much as about the transcendence of norm; about the unique as much as about the regular; about change as much as about monotony of reproduction; about the unexpected as much as about the predictable. (p. xiv) 
The reason is, Bauman explains, man-made order cannot exist without human freedom to choose and, needless to say, human freedom is meaningless if there is no change. However, it is to be noted here that Bauman does not talk only about "discontinuation", "pattern-breaking", or "change"; his definition implies a balance between the new and the old. Bauman substantiates his arguments by referring to Simmel (1968), who anticipates the futility of by-passing the complexity of culture to embrace it as a Parsonian "system" and to Levi Strauss who, in spite of being dubbed a structuralist, portrays "culture as a structure of choices—a matrix of possible, finite in number yet practically uncountable permutations" (Bauman, 1999, p. xxvi). After a thorough discussion on Simmel, Levi Strauss, and some other relevant authors, Bauman (1999) concludes:

...to "master a culture" means to master a matrix of possible permutations, a set never fully implemented and always far from completion - not a finite collection of significations and the art to recognize their carriers. What collects cultural phenomena into a "culture" is the presence of such a matrix, a constant invitation to change, not their "systemness"... (p. xxix)

In one way, his idea is echoed by Fang's (2011) dynamic paradigm of culture which centers around intercultural interaction where cultures are "negotiated, compromised, embraced, and transferred"; and in another way, his view supports "multiculturalism" which accepts "many separate and autonomous sets of values and behavioral norms" where "one dominant and uncontested cultural authority" is absent.

\section{Culture as "Hegemon"}

Although multiple sets of values and behavioral norms are more acceptable than a single dominant cultural authority to any modern democratic individual citizen or society, in reality, the globalizing world is being increasingly engulfed by certain domineering cultures. In the past, the nation-states formed the national cultures eliminating "all residues of custom and habit which did not fit the unified model" (Bauman, 1999, p. x), and now, according to Rothkopf (1997) and Friedman (1999), American/Western culture is spreading all over the world marginalizing and, sometimes, crushing the domestic cultural elements considered to be stumbling blocks on its way to globalizing the world. They even argue that in order to get the maximum benefits from globalization, a state would be better off sidelining some of its historic origins or cultural inheritance bowing to the inevitable American/Western cultural hegemony.

Some communist and Islamic states tired to adopt Parsonian "culture" but their movement towards the "center" of Wallerstein's (2006) capitalist world system was about to be constrained by the culture as "system". Hence in order to ensure and accelerate their progress towards the "center", they had to cautiously allow the foreign iconoclastic cultural elements pressing around their borders. Perhaps, the aim was to replace the Parsonian "system" with the Baumanian "matrix", but as at the age of globalization/Americanization, it is difficult to control the inflow of internet and media mediated American cultural elements, the Baumanian balance between novelty and tradition cannot be maintained. Therefore as neither the Parsonian "system" nor the Baumanian "matrix" seems to be feasible any more, to some states the only way to go forward, towards the "center" of the world system, is to adopt the culture of the world hegemon-Western culture in general and American culture in particular.

\section{Culture in English Language Textbooks}

Language, many scholars argue (Allwright \& Bailey, 1991; Byram, 1989), is integrated with culture which presupposes the necessity of the learners' acquaintance with the target culture for learning the target language in the true sense of the term. Thus, in the case of English they have to be familiar with Kachru's (1982) "Inner 
Circle" culture to attain the native-like proficiency in English. However, in the light of some research findings, it is very difficult to be familiar with the target culture directly without being conscious of learners' own culture (McKay, 2000, 2002; Ilieva, 2000). If the learners are confronted with the target culture only-which usually happens when they read the global course books - they cannot comprehend the reading texts easily (Ilieva, 2000; Ndura, 2004). Boriboon (2004) examines such a situation in Thailand and finds that the disparity between learners' daily lives and the discourse in the reading texts creates reading comprehension difficulties. Similarly, Blommaert (2010) argues that a language hardly functions in a community if it does not provide local meanings.

Conversely, as previously noted, intercultural competence, one of the main objectives of ESL learners like Saudi school students, cannot be attained if the language is presented only in the learners' own cultural context (Majdzadeh, 2002; Garci'a, 2005). Therefore, Victor (1999) and Majdzadeh (2002) suggest that the textbooks should contain local as well as target and global culture. Cortazzi and Jin (1999) argue on the same line; they believe that the textbooks may have "source culture materials" (students' native culture), "target culture materials" (target culture), and "international materials" (multi culture). Therefore, in a way, Cortazzi and Jin (1999), Majdzadeh (2002), and Garc1' a (2005) reflect the Baumanian view of culture as "matrix".

This paper investigates the cultural elements of the reading texts in terms of the categories, which, according to Cortazzi and Jin (1999), are supposed to be included in an ideal textbook. Islamic and Saudi cultural elements are found out as "source culture materials", Western cultural elements are sorted out as "target culture materials", and multicultural elements are identified as "international material". In order to recognize and classify the elements, Sharifian's (2011, pp. 8-11) way of interpreting culture is used. He interprets culture in terms of schemas which are shared by particular cultural groups rather than individuals. Sharifian specifically mentions five schemas: event, role, image, proposition, and emotion schemas, which are useful to sort out the presence of a specific culture in a textbook. Event schemas are abstracted from events; role schemas are taken from the knowledge of social roles that are expected of the people of certain positions; image schema is the schema of the iconic images; proposition schemas are the models of thought and behavior; and emotion schemas are the abstractions of emotions which are culturally specific. However, the four types of cultural element mentioned above are interpreted below for every book.

\section{Saudi Secondary English Textbook Data Analysis}

For this paper, as it is mentioned before, I have collected three third-grade secondary school textbooks-Saudi Arabian Schools' English, English for Saudi Arabia, and Traveller 3-taught one after another over the last 33 years and analyzed all the texts meant to develop the students' reading skills.

\section{Saudi Arabian Schools' English}

Saudi Arabian Schools' English was used for 16 years from 1982 to 1997. The titles of its 19 reading texts which are of almost equal length may provide a sketchy idea about the cultural elements it contains: (1) "All over the world", (2) "Ibn Battuta", (3) "Pollution”, (4) "Coffee”, (5) "Locusts", (6) "Our airports”, (7) "Carpets: a great Muslim skill", (8) "The Hejaz Railway", (9) "Radar: making the travel safe", (10) "The lowest place in the world", (11) "Volcanoes", (12) "Mercy to an enemy", (13) "Exporting our oil", (14) "The first time men flew", (15) "The Solar System", (16) "Mapmaking", (17) "How Islam came to the East", (18) "Arabic numbers", and (19) "Our language". 
The titles of the two chapters, "Carpets: a great Muslim skill" and "How Islam came to the East" clearly demonstrate that they are all about Islam. The text titled "Carpets: a great Muslim skill" describes the typical patterns, colors and the ways of weaving Muslim rugs. A few Islamic countries like Turkey, Iran, Afghanistan, Egypt, and Pakistan are mentioned here as the producer countries. The text contains at least two Muslim schemas: (1) an image schema of Muslim culture - typical Muslim rugs and (2) a proposition schema in the sentence-"Muslim rugs never have animals on them" (Field, 1982, p. 55) which reflects that, in Islam, drawing of living beings is forbidden. ${ }^{1}$ Moreover, all these local cultural elements are presented in localized English: the Arabic word "mihrab" (a typical raised structure built in front of the "imam", the person who leads the prayers in a mosque) is used here perhaps to make the text easier for the students or to avoid the difficulty of translating the culturally specific object to English. The other text "How Islam came to the East" contains the Muslim role schema of soldier as it describes how Islam was spread across Asia (Persia, Afghanistan, Bukhara, Samarkand, Khwarizm, Mukran, Multan, Pakistan, etc.) by the bravery of two great Muslim soldiers-Qutaybah Ibn Muslim and Mohammed Ibn Al-Qasim.

The Muslim role schema of soldier is again found in "Mercy to an enemy". The story is about the greatness, kindness, and courage of a legendary Muslim general, Salahuddin. During a war against King Richard I, when he knows that the King is very sick and about to die, he orders his Muslim doctors, who are "the best in the world" (Field, 1982, p. 109), to make some medicine for his arch enemy. When the medicine is made, he risks his own life to take the remedy himself to the enemy camp and hand it over to the King. Eventually, when the King is cured and learns that Salahuddin himself saves his life, he refuses to resume the war against this great soldier. In addition to role schema, the text also contains Muslim image and proposition schemas. Salahuddin himself has become an iconic figure among Muslims for many of his heroic deeds described above and elsewhere in innumerable texts. Almost all Muslims in general and Saudis in particular, get to know this incident either as a bedtime or a textbook story. Besides, Salahuddin can be regarded as an ideal Muslim soldier as he does exactly what a true Muslim should do to a sick woman or man irrespective of her or his creed, color, and class (Hilali \& Khan, 1998: 41: 34). A similar kind of proposition schema is found again in "Arab aid" (a text of the second book, English for Saudi Arabia, discussed below) where the rich Gulf countries" religious obligation to help the other Muslim and non-Muslim poor countries is mentioned.

The second text "Ibn Battuta" is about the famous Muslim traveller who "visited all the important Muslim countries" (Field, 1982, p. 17). The text has at least three Muslim schemas. Makkah-the holiest and the most important city to a Muslim - is a Muslim image schema. The emotion schema is clearly stated in the sentence where Ibn Battuta, like any Muslim, says that he likes Makkah most among all the cities he visited. There is also a Muslim role schema, where Ibn Battuta is presented as a Muslim traveller and "quadi" (a judicial position which is usually held by the wisest members of a Muslim society).

The Muslim schemas of "Makkah" and "Medinah" are found again in the text, "The Hejaz Railway". The story is about a railway from Damascus to Medinah which carries Muslim pilgrims to Makkah from different Muslim countries. The whole text is abstracted from the great event of establishing a railway to smoothen the pilgrimage of the Muslims from some neighboring Muslim countries to the holy cities. There is also a proposition schema in the phrase "non-Muslims were to leave the train at Ma'an, in today's Jordan" (ibid, p. 62) which reminds the readers of the Qur' anic verses barring the non-Muslims" entrance to the holy city of Makkah

${ }^{1}$ Sahih al-Bukhari. 3322. Retrieved from http://sunnah.com/bukhari/59/128. Accessed August 7, 2014. 
(Hilali \& Khan, 1998: 9: 28).

The Muslim image schema of Makkah is found again in the story "All over the world" where all the characters from different parts of the world turn towards the city when they pray. The story, as the title suggests, is supposed to be a text about the people from all over the world but they are from only four countries - India, Indonesia, Sudan, and Nigeria and moreover, all of them are from one religion-Islam. Therefore, the characters-Ali, Amir, Othman, and Musa—have many things in common like:

They all pray five times a day; and they all fast during Ramadan. Although they live a long way away, they all know where Makkah is; and they turn to it when they pray.... They can all read Arabic. All of them expect to come to the Kingdom [Saudi Arabia] one day, to perform their Hajj. Indeed Musa is hoping to perform his Hajj next year. (Field, 1982, p. 10)

The word "Makkah" is used here as an image schema as it does not mean the city only. When all the characters of the text (or any Muslim from any part of the world) turn to it while praying, they actually turn to the Ka'ba (Allah's house) not to the city of Makkah in the true sense of the term. ${ }^{2}$ Here "Makkah" signifies $\mathrm{Ka}$ 'ba - the small black house built by Prophet Ibrahim (peace be upon him) around 4,000 years ago, not the big city of Makkah built and evolved later on around the Ka'ba to the present form by different kinds of people at different times for diverse reasons.

The reading text "Arabic numbers" traces the history of numbers in the Arab and European world and stresses the fact that the Europeans "learnt their system [numbers] of counting from the Arabs [Muslim scholars]" (Field, 1982, p. 158) particularly from Al-Khwarizimi whose book influenced Europeans to use the numbers they are now using instead of the Roman ones. The text shows that the development of the system of numbers is associated with the spread of Islam and claims that "Arabs [Muslims] introduced something new and very important: the zero" (ibid, p. 159). Although most of the scholars agree that the Hindu mathematician and astronomer Brahmagupta invented "sunya" (zero) as a number of its own-both as an idea and a symbol - in A.D. 650, and by A.D. 773 the concept reached Baghdad and was included in the Arabic number system (Wallin, 2002). Therefore, the statement about some Muslim's invention of zero may be considered to be an Arab emotion schema.

The text "Our language" claims that Arabic is one of the two most important languages (the other being English) in the world. It is important because:

...it is the language of the Holy Qur'an. Most Muslims learn Arabic as their second language; and it has become the common language of the Muslim world. Only through Arabic can pilgrims of different nationalities communicate with others when they arrive in Makkah. (Field, 1982, p. 166)

In addition to that, Europeans had to learn Arabic in order to learn mathematics, medicine, and engineering from Arab scholars and this is the reason why it cast a wide influence on other languages like English and Spanish. The text ends with the belief that the Fussa Arabic (the language of the Qur'an) "remained unchanged for well over a thousand years [Muslims also believe that it will never change (Hilali \& Khan, 1998: 15: 9)], because it is the language of the Qur'an" (Field, 1982, p. 166). Two other texts- "Our Airports" and "Mapmaking" state Saudis' pioneering role in developing a new Muslim architecture in the airport buildings of Dahran, Jeddah, and Riyadh as well as a Muslim mapmaker Al-Idrisi's epoch-making

${ }^{2}$ Sahih Muslim. 526 a. Retrieved from http://sunnah.com/muslim/5/18. Accessed August 7, 2014. 
contribution to modern mapmaking.

The use of the possessive pronoun "our" in the titles like "Our airports" and "Exporting our oil" make it crystal clear that they are all about Saudi Arabia. "Our airports" reveals Saudi image and emotion schemas. It describes the two most important airports of Saudi Arabia: King Khalid International Airport at Riyadh and King Abdul Aziz Airport at Jeddah and proudly claim: "The Kingdom [Saudi Arabia] leads the world in showing that airports can be beautiful buildings" (ibid, p. 47). The text also describes Saudia, Saudi Arabia's national airline, and predicts that it will be a very big airline and will train and employ the Saudis in both planes and airports. Another text "Exporting our oil" is about the most precious natural resource of Saudi Arabia. It describes how Saudi oil is exported through oil tankers giving a particular example of oil export from Saudi Arabia to Britain. The text "Coffee" narrates how the Arabs learnt to drink coffee and how they transmitted the drink to Europe like they did in the case of mathematics as a link between India and Europe discussed in "Our Numbers".

The Western culture is presented through only one text "The first time men flew" which describes the invention of the plane by Orville and Wilbur brothers - one of the greatest American event schemas. The text is illustrated with a photograph of a first generation plane surrounded by the people attired in western dress. Other cultural elements are not included in Saudi Arabian Schools' English. The texts about pollution, locusts, radar, deep sea, volcanoes, and the solar system are culturally non-specific.

The western author of the book, John Field, clearly views Saudi national culture as a "system" and is very careful not to upset it by any means. The single text about Western culture is chosen in such a way that it does not even disturb the "system". All other culturally specific texts tend to focus on Islamic and Saudi culture. For example, in the book, only the buildings which have Muslim architectural design, like the airport buildings of Jeddah and Riyadh, are mentioned; the texts about airports discuss only Saudi airports; the text about airline discusses only the Saudi airline, Saudia; the text about mapmaking focuses on a Muslim mapmaker Al-Idrisi; the text about coffee stresses the Muslims' role in the introduction of coffee to Europe; the text about the history of numbers also proudly asserts Muslim scholars' contribution to developing the discipline and spreading it across Europe, and so on and so forth. Likewise, the language is also localized by using Islamic and Saudi contexts, incorporating Arabic words like "mihrab", "Hajj", "Makkah" (signifying Ka'ba), and "Medinah" etc., and avoiding idiomatic "Inner Circle" English.

\section{English for Saudi Arabia}

English for Saudi Arabia was used for 15 years from 1998 to 2012. It has six reading texts of almost equal length: "Water", "Conservation", "Air travel in Saudi Arabia", "The holy month of Ramadan", "Earth planet", and "Arab aid". Only three among these six texts are culturally specific and they are written either in Islamic or in Saudi contexts.

There is only one text in the textbook "The holy month of Ramadan" which is totally dedicated to Islam. The text begins with the "five pillars of Islam" in the following way:

The first belief is that there is no god but Allah [bold and italics in the original] and that Muhammad (peace be upon him) is his Messenger. The second is that a Muslim must pray five times a day at certain times, and the third is that a Muslim must give a percentage of his savings to the poor. The fourth is the fasting of Ramadan [bold and italics in the original]. The fifth is that all Muslims who are able should perform Al-Hajj (Pilgrimage) at least once in their lives. (Ministry of Education, 1998, p. 48) 
The introduction of "five pillars" is followed by a discussion of Ramadan (the ninth month in the Islamic calendar when the Holy Qur'an was revealed and when the Muslims fast from dawn to dusk) in detail: Who are to fast, how to fast, why to fast, and when to fast. The last two paragraphs are about two important days for a Muslim: Lilatul Qadr (one of the last ten nights of Ramadan when she/he seeks blessings from Allah) and Eid-Al-Fitr (day of celebration immediately after Ramadan when she/he wears new clothes and receives/gives gifts and thanks Allah for revealing the Qur'an).

The Muslim image schema of "five pillars", the role schema regarding a Muslim's duties and responsibilities, the event schemas of Eid-AL-Fitr and Lailatul Qadr, the proposition schema of the way of pronouncing the name of Prophet Muhammad (every Muslim utters the phrase "peace be upon him" when he articulates and hears his name) are very important in a Muslim's life. One other text-"Arab aid"- has only one passing reference to a crucial Islamic proposition schema "Zakat" (obligation of giving a certain portion of a Muslim's savings to the poor), mentioned above, as one of the five pillars of Islam.

Two texts are directly related to Saudi Arabia: "Air travel in Saudi Arabia" and "Arab aid". "Air travel in Saudi Arabia" narrates the history of Saudi Arabia's national airlines-Saudia. The airlines started in 1945 with a single Douglas DC-3, a gift from the American President Franklin D. Roosevelt. Since its inception, it has been growing fast and now it has become one of the biggest airlines of the world. The other text "Arab aid" describes the financial help that Saudi Arabia and other Gulf countries extend to the poorer countries. These Muslim countries give this aid for two reasons: as a way of making friends in the developing world and as "Zakat".

There are neither Western nor multicultural elements in the reading texts of English for Saudi Arabia. The other three texts about water, conservation, and the Earth are culturally non-specific.

English for Saudi Arabia, like the previous book Saudi Arabian Schools' English is very carefully written lest the "system" of Saudi national culture should be disturbed. Although only three among six reading texts - "The holy month of Ramadan", "Air travel in Saudi Arabia", and "Arab aid"—contain Islamic and Saudi cultural elements, the author/authors (the names are not mentioned in the book) avoid Western and multicultural elements in the other three texts - the border of the "system" is diligently guarded, so to say. The language is also localized by the use of local contexts and Arabic words like: "Allah", "Qur'an", "Muhammad (peace be upon him)", "Ramadan”, “Al-Hajj”, "Maghrib” (the sunset prayer), "Lailatul Qadr", "Eid-Al-Fitr" etc. In comparison with the former book, Saudi Arabian Schools' English, this book is more rigid about pattern maintenance.

\section{Traveller 3}

Traveller 3 is a KSA edition of a global course book published as a pilot edition in 2013. It has seven modules and each module has two pages (e.g., 1a, 1b, 2a, 2b etc.), meant exclusively for developing the reading skill. In addition to these, four other culture pages, which can also be used for developing reading skill, are analyzed below. However, the reading texts meant for enhancing listening skill are not discussed here.

Only two texts contain Islamic culture- "Salah Al-Din: a true hero", and the second story of $2 \mathrm{~b}$ - "Lone man survives crash unharmed". The story titled "Salah Al-Din: a true hero" contains Islamic image, role, and event schemas. It is, in fact, another version of the story "Mercy to an enemy" included in Saudi Arabian Schools' English presented in a slightly but significantly different way. For example, the name and character of Salah al-Din is spelled and portrayed in different ways. On the one hand, Salahuddin is spelled here as Salah 
al-Din and on the other; instead of a merciful character, he is rather portrayed as an intelligent leader whose careful plans and skills win the heart of his enemy, King Richard I. Therefore, naturally, Richard I is not as impressed by Salah al-Din's friendly gesture in the second story, as he is by Salahuddin's "mercy" in the first text, to refuse to fight the Muslims after his recovery. In this story, neither Salahuddin in particular nor the Muslims in general are as glorified as they are in the first text.

In the first text, as mentioned before, Muslim doctors are praised to be the best in the world, but they are not praised at all for their professional excellence in the second text. In fact, Salah al-Din's doctor does not give any medicine to King Richard in the second text; he takes only fruits and ice with him. In the first text, Salahuddin's doctors are so good that they can save a serious patient's life without diagnosing or even seeing him; whereas, in the second text, the doctor does not even try to make any medicine, he simply brings some ice and fruits, which a king should not be in need of while staying at his own camp surrounded by his own army. As a matter of fact, Salah al-Din's doctor's visit to King Richard is more like a courtesy call than a professional visit. Hence, there is no point of terming Salah al-Din's friendly gesture as mercy as it is done in "Mercy to an enemy" of Saudi Arabian Schools' English. Furthermore, the visit in the second text is not as dramatic as the first one-here Salah al-Din does not risk his own life to trespass on the enemy camp in disguise. The fact that the two stories about the same incident are written from two vantage points is clear: The first one focuses on the greatness and extraordinary expertise of Salahuddin and his Muslim doctors respectively while the second one, perhaps in order to rationalize the story in the western way, shifts the focus to Salah al-Din's strategy of winning the heart of King Richard. However, the way the well-known story is repeated in the second text can be termed as Derridian iteration (the novelty ingrained in every act of repetition) - an essential phenomenon of culture as "matrix".

There is also a remarkable change in the use of language - the former text is written in localized English while the language of the latter is idiomatic "Inner Circle" English. The following few lines from the two texts will suffice to illustrate the point.

(1) The great Muslim soldier, Salahuddin, was fighting against King Richard of England. One day, he heard that King Richard was very ill, and could not lead his army (Field, 1982, p. 109).

(2) For two years Salah al-din and King Richard fought against each other, the former protecting and the latter trying to win Jerusalem.

One day, word got around that King Richard was wounded (Mitchell \& Malkogianni, 2013, p. 22).

The non-idiomatic language of general vocabulary in the first text- "One day, he heard that King Richard was very ill"- is replaced with idiomatic English of specific words in the second text- "One day, word got around that King Richard was wounded" (my emphasis).

Another reading text seems to be an Islamic text for the photograph of a young Muslim with beard and "kalansuatun" (a kind of cap which the Muslims wear while praying) named Sameer Attar. This is the second story of $2 \mathrm{~b}$ - "Lone man survives crash unharmed" about the only survivor of a train crash. In spite of being illustrated with a picture of a Muslim young man, the story can be of any country where people commute by train. The story rather fits more a non-Muslim context than a Muslim one as the first thing that a Muslim is supposed to utter after surviving such an accident is "Alhamdulillah" (all praises are for Allah). Here neither Sameer nor his father thanks or praises Allah. A Muslim (particularly a Saudi) invariably adds "Alhamdulillah" to the sentence that Sameer utters, "I never bruised very easily" (Mitchell \& Malkogianni, 2013, p. 28). When he is asked about how he survived, he does not acknowledge the fact that he was saved by Allah, which a 
Muslim (particularly a Saudi) inevitably and automatically does in the aftermath of such an accident. Therefore, the use of the name and the photograph of a Muslim in otherwise non-Muslim text might be explained to be a weak attempt of "editionizing" the global textbook (the same kind of "editionizing" is found again in $3 a$ where the characters have Muslim/Arab names like Saad or Faisal in otherwise western stories). The story fits less the Saudi Arabian context than a western one, as the trains are the least used transport in Saudi Arabia. The country has a very short railway line between Riyadh and Dammam—only a four hour trip.

In Traveller 3, Saudi culture is introduced in the fourth text of "Why not consider volunteering to save planet Earth?" through the discussion of a recent flood that inundated Jeddah and an international charitable organization Charity Warehouse working in Saudi Arabia. This is, in fact, a call for the volunteers to work in Charity Warehouse to help the flood affected people in Jeddah.

Western culture is introduced through 18 texts: two short texts ("Super dad saves child" and "Climbers survive the worst") from $2 b$, four short texts about four different teenagers (Saad, James, Faisal, and Bob) from 3a, "Tips for a successful interview", three short texts from "Why not consider volunteering to save planet Earth?", "Hungry burglar caught red-handed", "Pedal away", "Beam me up Scotty”, "Learning English with new technology", "The high-tech adventures of a travelling food writer", and three texts from three different culture pages.

$2 \mathrm{~b}, 3 \mathrm{a}$, and $4 \mathrm{a}$ are all written in a similar vein, in the sense that all of them consist of a few short stories. $2 \mathrm{~b}$ has three texts: "Super dad saves child", "Lone man survives crash unharmed" (discussed above), and "Climbers survive the worst". "Super dad saves child" and "Climbers survive the worst" represent western culture: The characters like Andy Clemens or Marvin Bailey and the photographs used here are clearly western.

3a consists of four stories about four teenagers-Saad, James, Faisal, and Bob. Saad is a bookworm, and he wants to be a writer. James is sporty and athletic. He does scuba-diving, windsurfing, and rock-climbing. Faisal is really into surfing the net and playing strategy games on his computer. Although he hangs out at the local sports club, he is not so athletic. Bob is very sociable, and he loves sports and food. Among the four names, Saad and Faisal are Muslim/Saudi names, as mentioned above, and the other two are obviously western. However, apart from the names, there is nothing Islamic or Saudi here. It is not mentioned here whether Saad reads any book related to Islam or Saudi Arabia-he reads "anything from adventure to science fiction" (Mitchell \& Malkogianni, 2013, p. 38). If Saad were representative of the Muslims or Saudis, he would recite the Holy Qur'an or read the Hadith (sayings or actions of Prophet Muhammad - peace be upon him) most of the time as to a Muslim in general or to a Saudi in particular, the Holy Books are the source of all knowledge (Hilali \& Khan, 1998: 27: 75-79) on the one hand and on the other, there is a religious obligation to read the Holy Qur'an regularly. ${ }^{3}$ The picture tagged on Saad's story is the image of a cover page of Jules Verne's $A$ Journey to the Center of the Earth, one of the famous adventure novels of the western world. All other illustrations given and sports mentioned here are clearly western. Therefore, Saad and Faisal are Muslims only in name. They do not have any characteristics related particularly to Islam. This is again an unsuccessful attempt to "editionize" the global course book.

The text "Why not consider volunteering to save planet Earth?" (4a) has four advertisements for volunteering to save the planet earth. The first advertisement calls for volunteers for Global Youth for Environmental Protection (GYEP) to change the "grey" economy, based on habits that are harmful to the

${ }^{3}$ Sahih Muslim. 790 b. Retrieved from http://sunnah.com/muslim/6/270. Accessed August 7, 2014. 
environment to "green" economy, based on the understanding that we need to protect our environment. The second advertisement is a call for the volunteers for National Science Foundation (NSF) to save the Amazon Basin. The third advertisement is about saving the beaches of the Bahamas and Florida joining the Coastal Ecology Center (CEC). The last is about Charity Warehouse in Jeddah (discussed above).

The Western world of work and business is introduced in "Tips for a successful interview" (3b). The text intends to make the students aware of the skills and strategies so that they can impress western job interviewers. Therefore, most of the tips fit more a western country than Saudi Arabia. For example, in the case of clothing it does not fit Saudi Arabia at all as the text asserts that a business suit, a western image schema for male clothing, is always acceptable, whereas, in Saudi Arabia, the national/official dress is the "thobe" (the traditional Arab clothing) not a business suit. It is to be noted here that the Saudis are very strict about maintaining their official dress code.

There are three technology related stories in a row: "Beam me up Scotty" (6b), "Learning English with new technology" (7a), and "The high-tech adventures of a travelling food writer" (7b). The first story, "Beam me up Scotty", is about Gene Roddenberry's famous science fiction series Star Trek and the technological ideas it generated. The text also discusses its linguistic influence on the viewers; the phrase "Beam me up, Scotty" became a catchphrase for a whole generation of Star Trek fans. The second story "Learning English with new technology" is about four technology based English language learning methods-E-learning, virtual classrooms, tandem e-mail, and interactive CDs. The western interactive learning methods discussed here are supposedly foreign to Saudi Arabia where the long and deeply rooted tradition of teacher-centeredness seems to be the norm (Elyas \& Picard, 2010). "The high-tech adventures of a travelling food writer" (7b) by Bob Briscoe is about visiting London to see how the new restaurants are using technology to change the way people dine out. The writer visits high tech Italian, Indian, and Spanish restaurants and eats pasta, extra-spicy curry, and tapas.

The incidents of the two stories "Hungry burglar caught red-handed" and "Pedal away" happen in the USA, the Netherlands, and Belgium. In "Hungry burglar caught red-handed" (5b), a burglary takes place in Montville, New Jersey, in the houses of Tony Green, Tim, Miranda and others. The burglar, a homeless man, steals only home-cooked meals. "Pedal away" (6a) is a text about a guided bicycle tour from Amsterdam to Brussels. The route of the tour is through the city of Breukelen, Castle de Haar, the old town of Hertogenbosch, the Belgian border, the Flemish port town of Antwerp, the beautiful Flemish countryside, and then the final destination to Brussels. The tour ends with a dinner of typical Belgian specialties such as mussels, chips, and waffles. The cost of the tour is 635 euros.

Four culture pages named Culture Page 1, Culture Page 2, Culture Page 3, and Culture Page 4, are also used as reading material. The first culture page is about two western heroes: Wayne Gretzky—one of the greatest players in the history of ice hockey and Sir Edmund Hillary-a mountaineer, explorer, and philanthropist from New Zealand. The second culture page is about a natural wonder of the west-Giant's Causeway of Northern Ireland. The third is about Brendan's claim about the discovery of America before Columbus. According to Brendan's description, he reached America 900 years before Columbus by a tiny boat which, to many ears, sounds like a fairy tale. However, to find out whether Brendan's claim was true or not, Tim Severin, with four crew members, sailed from Ireland by the same kind of boat that Brendan used for his journey and reached America. The last culture page is about aboriginal Australians. All the texts are clearly western, except for the last one. 
Traveller 3 introduces multicultural elements in four reading texts: "It's a small world!", "The power of color: the meaning of colors in different cultures", Culture page 4, and in "The island of Rapa Nui". Among them, both of the first two texts contain cultural elements of a number of countries from all of Kachru's (1982) "Inner", "Outer", and "Expanding" Circles. "It's a small world!" describes a theme park where the most famous sites of the world are squeezed onto 480,000 sq metres area. Besides the Pyramids, Islamic Street, and Indian culture, all other things referred to in the text are western, like the Grand Canyon, the Acropolis, the Niagara Falls, and the Eiffel Tower. It is to be noted here that the first text of Saudi Arabian Schools' English has a similar title- "All over the world" but, as discussed above, that is not a window on the world in the true sense of the term, as all of its characters are Muslims and the writer delineates them in such a way that they are in no way different from Saudis in terms of religion. The other text "The power of color: the meaning of colors in different cultures" (1b) describes different meanings of color in different countries like China, North America, Saudi Arabia, Myanmar, Egypt, Ireland, etc.

Culture Page 4 and "The island of Rapa Nui" describe two ancient peoples: aboriginal Australians and the early inhabitants of Rapa Nui. Culture Page 4 describes aboriginal Australians' history, tradition, storytelling, and ceremonies (or "corroborees") with one of their rock paintings in the background. On the other hand, "The island of Rapa Nui" (5a) describes a small island in Pacific Ocean called Rapa Nui discovered by Dutch explorer Jacob Rogeveen in 1722 and James Cook in around 1772. The text describes its geographical location, history, mystery, inhabitants, and its most famous enormous statues (approximately six hundred) with a big photograph of one of the "moai" statue heads. The photograph might be considered as one of the significant pattern-breaking elements as this kind of statues is forbidden ${ }^{4}$ in Saudi Arabia since they might engender "shirk" (establishing "partners" placed beside Allah) — an unforgivable sin in Islam. This is the reason why Saudi Arabia does not allow any kind of sculpture indicating a human head or face inside its territory.

Traveller 3 has only one culturally non-specific reading text- "Animal SOS". All other texts contain one kind or other cultural elements and none of them (except "Salah Al-Din: a true hero") care for the pattern-maintenance. The essential parts of the "system" of Saudi national culture-Muslim event, image, role, proposition and emotion schemas - are almost absent in the reading texts discussed above. It is true that Salah al-Din's story reveals Islamic image and role schemas, but as it is argued above, it rationalizes the characterization and plot in the western way and avoids the emotion schema of eulogizing adjectives for Muslims used before in a similar text, "Mercy to an enemy" of Saudi Arabian Schools' English. In short, Traveller 3 is quite opposite to the former two books in terms of cultural elements. The foreign cultural elements, which are cautiously assimilated to the Saudi context in Saudi Arabian Schools' English and avoided in English for Saudi Arabia, are found in plenty without any modification or assimilation whatsoever in Traveller 3. On the contrary, even a few local elements are westernized in order to accommodate them in the Western cultural patterns pervading Traveller 3.

\section{Discussion}

The data discussed above are put in the Table 1 below to get a comprehensive idea about the direction of changes. The table shows the book wise space allocated for each category in terms of number of texts.

${ }^{4}$ Sahih Muslim. 5250. Retrieved from http://www.sahihmuslim.com/sps/smm/. Accessed August 7, 2014. 
Table 1

Number and Percentage of Texts for Each Type of Cultural Element

\begin{tabular}{|c|c|c|c|c|c|c|}
\hline Textbook & $\begin{array}{l}\text { Total No. of } \\
\text { reading texts }\end{array}$ & $\begin{array}{l}\text { Texts (Islamic) } \\
\text { Nos }(\%)\end{array}$ & $\begin{array}{l}\text { Texts (Saudi) } \\
\text { Nos }(\%)\end{array}$ & $\begin{array}{l}\text { Texts (Western) } \\
\text { Nos }(\%)\end{array}$ & $\begin{array}{l}\text { Texts (Multi) } \\
\text { Nos }(\%)\end{array}$ & $\begin{array}{l}\text { Texts (Culturally } \\
\text { non-specific) } \\
\text { Nos (\%) }\end{array}$ \\
\hline $\begin{array}{l}\text { Saudi Arabia Schools' } \\
\text { English }\end{array}$ & 19 & $\begin{array}{l}9 \\
(47.36 \%)\end{array}$ & $4(21.05 \%)$ & $\begin{array}{l}1 \\
(5.26 \%)\end{array}$ & $\begin{array}{l}0 \\
(0 \%)\end{array}$ & $\begin{array}{l}5 \\
(26.31 \%)\end{array}$ \\
\hline English for Saudi Arabia & 6 & $\begin{array}{l}1 \\
(16.66 \%)\end{array}$ & $\begin{array}{l}2 \\
(33.33 \%)\end{array}$ & 0 & $\begin{array}{l}0 \\
(0 \%)\end{array}$ & $\begin{array}{l}3 \\
(50 \%)\end{array}$ \\
\hline Traveller 3 & 26 & $\begin{array}{l}2 \\
(7.69 \%)\end{array}$ & $\begin{array}{l}1 \\
(3.84 \%)\end{array}$ & $\begin{array}{l}18 \\
(69.23 \%)\end{array}$ & $\begin{array}{l}4 \\
(15.38 \%)\end{array}$ & 1 \\
\hline
\end{tabular}

It is clear that the number of Islamic texts is reduced steadily from book to book- a clear pattern of "the older the more and the newer the less". In the case of Saudi culture it is obviously different-in proportion to other elements, it gets more importance in the second book than in the first one but then it is pushed suddenly out of its central position to the periphery in the third book. If we look at the Islamic and Saudi texts together, as both of them contribute to the self-styled, self-enclosed Parsonian "system" maintenance, we find that they constitute a large part of the first two books. In Saudi Arabian Schools' English, 68.41\% consists of religious and local elements; only $5.26 \%$ consists of western elements; and the rest of it is culturally non-specific. Similarly, in English for Saudi Arabia, the texts which are culturally specific contain only the Islamic and Saudi elements. However, the trend changes radically in Traveller 3 where Islamic and Saudi elements constitute only $11.53 \%$ which is less than the multicultural elements $(15.38 \%)$ and insignificant in comparison with the western ones (69.23\%). Moreover, the modification and assimilation happen the other way round - instead of western elements the local ones are adapted to Western cultural patterns. The dramatic rise and fall of the four types of cultural element discussed above is probably more obvious in the following Figure 1.

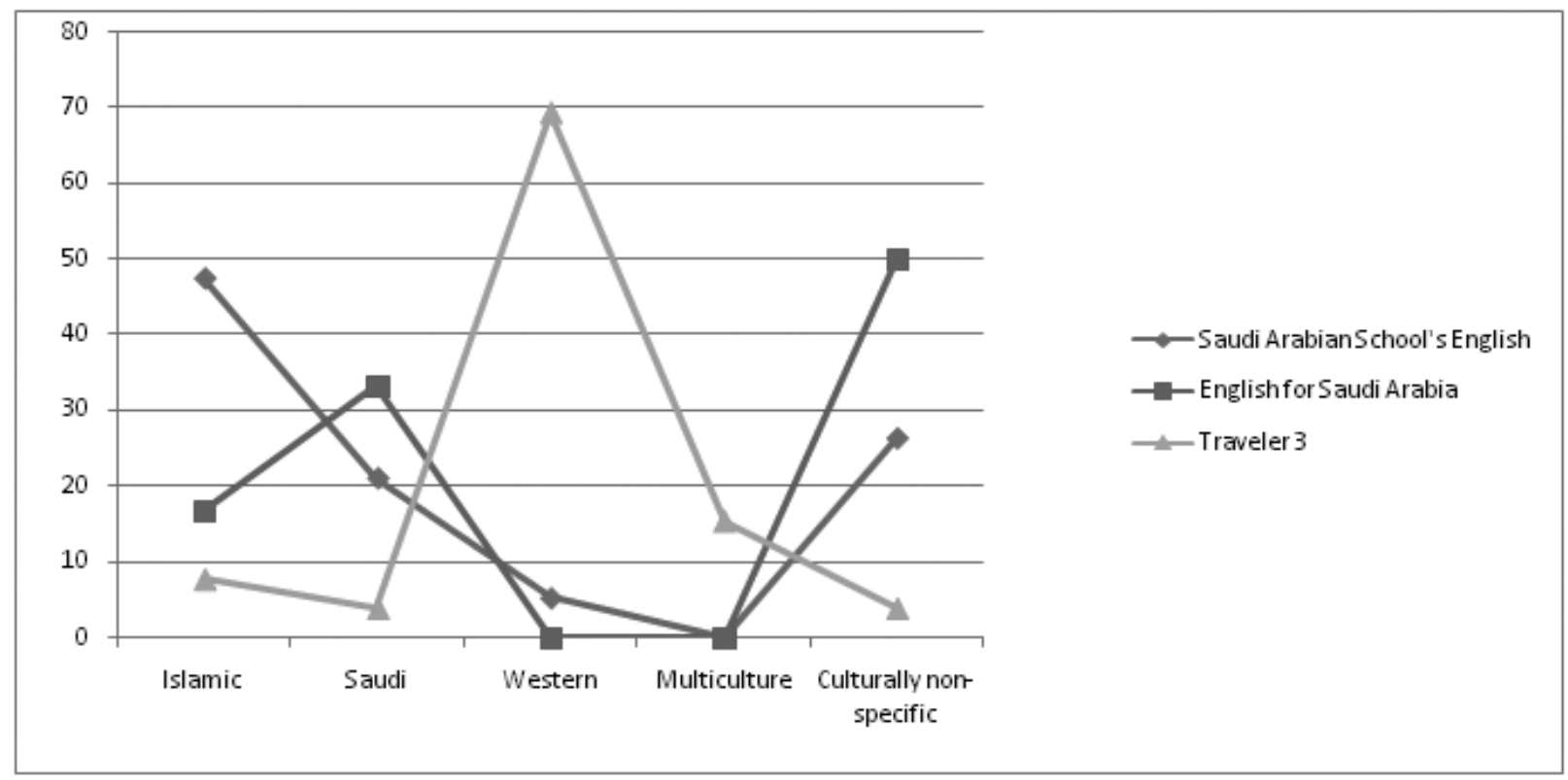

Figure 1. Textbooks' changing cultural patterns.

Both the first and the second books Saudi Arabian Schools' English and English for Saudi Arabia conform to the Parsonian view of culture as "system". In contrast, the third book, Traveller 3, adopts "system"-breaking 
elements and, in order to make the "system'-breaking" a norm, it ignores such Baumanian elements as "continuation", "tradition", or "preservation"- the essential components of culture as "matrix".

The third book gives such free access to the "pattern-breaking" items that it seems all the border guards are withdrawn suddenly and the self-enclosed "system" is flooded overnight with the waves of elements that it has been resisting for at least more than one hundred years. From Rothkopf's (1997) and Friedman's (1999) point of view, withdrawal of the guards is a prerequisite to replace the local and domestic cultures with American/Western culture which is necessary to increase the pace of movement for any globalizing state such as Saudi Arabia towards the "core" zone of Wallerstein's (2006) modern "world system" (the capitalist system). Nevertheless, a perusal of Traveller 3 illustrates the fact that nothing un-Islamic is included in the textbook - the western elements are chosen so carefully that they do not contradict Islamic culture. Furthermore, someone might even argue that the book is written in tune with the faith of Islam, as the Qur'an encourages Muslims to get to know other peoples. In the Qur'an (Hilali \& Khan, 1998: 49: 13), Allah says: O mankind! We have created you from a male and a female, and made you into nations and tribes, that you may know one another (p. 13).

\section{Conclusion}

It is evident from the above discussion that the last book Traveller 3 tries to get rid of the Parsonian view of culture as "system" to provide a huge space for the western and multicultural elements. However, getting away from the Parsonian view does not mean that it adopts the Baumanian view of culture as "matrix". It simply tries to promote the global citizenship of the young Saudis, and acquaint them with the other cultures, mostly the Western culture, so that they can learn the "Inner Circle" English, not the local one, and accelerate the state's movement from the "semi-periphery" to the "core" zone of Wallerstein's "world system". Nevertheless, the question remains, why the change has been brought about so suddenly. This can be explained only by Saudi Arabia's state policy to jump towards the "core" zone and reach there very quickly in only a matter of ten years by 2024 (The Ministry of Economy and Planning, 2006).

\section{References}

Allwright, D., \& Bailey, K. M. (1991). Focus on the language classroom: An introduction to classroom research for language teachers. Cambridge: Cambridge University Press.

Bauman, Z. (1999). Culture as praxis. London: Sage Publications.

Blommaert, J. (2010). The sociolinguistics of globalization. Cambridge: Cambridge University Press.

Boriboon, P. (2004). We would rather talk about plaa raa than hamburgers: Voices from low proficiency EFL learners in rural Thailand. Paper presented at the Postgraduate Conference, Edinburgh, UK.

Byram, M. (1989). Cultural studies in foreign language education. Clevedon: Multilingual Matters.

Cortazzi, M., \& Jin, L. (1999). Cultural mirrors: Materials and methods in the EFL classroom. In E. Hinkel (Ed.), Culture in second language teaching and learning (pp. 196-219). Cambridge: Cambridge University Press.

Fang, T. (2011). Yin Yang: A new perspective on culture. Management and Organization Review, 8(1), 25-50.

Field, J. (1982). Saudi Arabian schools’ English. Hong Kong: Macmillan.

Friedman, T. L. (1999). The Lexus and the olive tree. New York: Farrar, Straus, Giroux.

Gray, J. (2010). The branding of English and the culture of the new capitalism: Representations of the world of work in English language textbooks. Applied Linguistics, 31(5), 714-733.

Garcı'a, M. (2005). International and intercultural issues in English teaching textbooks: The case of Spain. Intercultural Education, 16(1), 57-68.

Hilali, M. T., \& Khan, M. M. (1998). Translation of the meanings of the noble Qur'an in the English language. Medina: King Fahd Complex for the Printing of the Holy Qur'an. 
Ilieva, R. (2000). Exploring culture in texts designed for use in adult ESL classrooms. TESL Canada Journal, 17(2), 50-63.

Kachru, B. B. (Ed.). (1982). The other tongue: English across cultures. Urbana: University of Illinois Press.

Majdzadeh, M. (2002). Disconnection between language and culture: A Case study of Iranian English textbooks. (ERIC Document Reproduction Service No. ED 474 691)

McKay, S. (2000). Teaching English as an international language: Implications for cultural materials in the classroom. TESOL Journal, 9(4), 7-11.

McKay, S. L. (2002). Teaching English as an international language: Rethinking goals and approaches. Oxford: Oxford University Press.

Ministry of Education. (1998). English for Saudi Arabia. Riyadh: Ministry of Education, KSA.

Mitchell, H. Q., \& Marileni, M. (2013). Traveller 3. Greece: MM Publications.

Ndura, E. (2004). ESL and cultural bias: An analysis of elementary through high school textbooks in the western United States of America. Language, Culture and Curriculum, 17(2), 143-153.

Parsons, T. (1937). The structure of social action. New York: McGraw-Hill.

Parsons, T. (1966). Societies. N. J.: Prentice-Hall.

Parsons, T. (1977). On building social system theory: A personal history. In T. Parsons (Ed.), Social systems and the evolution of action theory (pp. 22-76). New York: Free Press.

Ritzer, G. (1996). Sociological theory. New York: McGraw-Hill.

Rothkopf, D. (1997). In praise of cultural imperialism? Foreign Policy, 107, 38-53.

Sharifian, F. (2011). Cultural conceptualizations and language (Vol. 1). Amsterdam: John Benjamins.

Simmel, G. (1968). On the concept and the tragedy of culture. In K. P. Etzkorn (Ed.), George Simmel (pp. 29-30). New York: Teachers college, Columbia University.

The Ministry of Economy and Planning. (2006). Ninth development plan. Retrieved from http://www.jeg.org.sa/data/ modules/contents/uploads/infopdf/1820.pdf

Victor, M. (1999). Learning English in Gabon: The question of cultural content. Language, Culture and Curriculum, 12(1), 23-30.

Wallerstein, I. (2006). World system analysis: An introduction. Durham: Duke University Press.

Wallin, N. B. (2002). How was zero discovered? Retrieved from http://yaleglobal.yale.edu/about/zero.jsp 